\title{
THE HISTORICAL CONTEXT OF THE WOODHOUSE COMMISSION
}

\author{
Brian Easton*
}

The Woodhouse Report provides an instructive model for effective advocacy, in that its proposals aimed to solve a clearly defined social problem: meeting the needs of accident victims in an equitable and comprehensive fashion. Moreover the Report presented its solution as a costeffective way of meeting broader compensation needs, by making existing economic resources go further. This paper argues that the Woodhouse model achieved success largely because of its problem-based clarity and sensitivity to cost efficiency. It also places the Woodhouse treatment of personal injury litigation in a larger historical pattern of evolution in common law.

Although it is rarely presented this way, policy making is a problem solving exercise. At the heart of the success of any solution is how well the problem is addressed. ${ }^{1}$ This approach, analogous to Karl Popper's approach to the development of science, requires us to be "as clear as you can about the problem, and watch the way it changes". ${ }^{2}$ A task then, of an historian, is to identify the problem or problems which drove a solution.

\section{THE HISTORICAL ORIGINS OF THE PRACTICE OF COMPENSATION}

The principle of compensation for personal injury seems to have arisen in Europe as a means of offsetting retribution by the injured and their families. As J G Fleming, who was cited by the Woodhouse Commission, comments: ${ }^{3}$

At the dawn of common law and for long thereafter, crime and tort covered much the same ground, both stemming from a common desire for vengeance and deterrence and distinguishable only by the nature of their respective sanctions ... [t]ort liability ... provided a means whereby the victim could be "bribed"

* I am grateful to Adam Clayton and Richard Gaskins for comments which helped improve this paper.

1 Brian H Easton The Commercialisation of New Zealand (Auckland University Press, Auckland, 1997) 255264.

2 Karl R Popper Objective Knowledge: An Evolutionary Approach (Clarendon Press, Oxford, 1972) 265-6.

3 John G Fleming An Introduction to the Law of Torts (Clarendon Press, Oxford, 1985) 2. 
into abstaining from retaliation by being able to compel the perpetrator to render him monetary compensation for the wrong.

In pre-industrial societies this was probably a rough and ready solution to a practical problem. The Maori had a similar principle of utu. ${ }^{4}$ No doubt many minor infringements in European life were dealt with by an informal utu-like process within the community, but the existence of the supreme authority of law limited the grievance process to creating the further retaliation in which Maoridom got bogged down on occasions.

However these solutions to the problem of how to limit vengeance and deter injury proved inadequate in the industrial society. Communities were broken up and interactions - and the possibility of injury - between strangers became more common. The breakdown of feudal and quasi-feudal relations changed the obligations of employers towards employees. New production processes (including new modes of transport) generated greater possibilities of accidents both in terms of number and degree of injury. Perhaps too, as life lengthened and expectations of an afterlife shortened, the importance of fair resolutions became a matter of concern.

From the nineteenth century British common law attempted to cope with the new circumstances by breaking the narrow compass within which the embryonic law of negligence had been gestating, extending it beyond the time hallowed consensual relations of doctor and patient (and so forth) into a vast range of informal situations symbolised by collisions at intersections or level crossings, open coal chutes in public streets, and bags of flour dropping from warehouses on passing pedestrians. ${ }^{5}$

But common law extensions proved inadequate, especially for factory injuries. A notable failure was the "fellow-servant rule" usually ascribed to Lord Abingner's opinion in Priestley $v$ Fowler in 1837, who held that in employment relationships of tradesmen the servant had no cause of action following an employment accident. ${ }^{6}$ The opinion, described as "diffuse and unperceptive", seems more an eighteenth century concern about the disruptive effects of a master's liability upon his household staff, than a recognition of looming nineteenth century industrial realities. ${ }^{7}$

The "doctrine of common employment" was put on a more rigorous basis by Chief Justice Shaw of Massachusetts in 1844 who observed there was a contract between employer and employee which did not usually mention indemnification for injury from industrial accidents (whereas there was no such formal contract between an employer and the public). ${ }^{8}$ The notion was that an

4 Raymond W Firth Economics of the New Zealand Maori (Government Printer, Wellington, 1967).

5 Fleming, above, 3.

6 Priestley v Fowler (1837) 150 Eng Rep 1030, 1032-33.

7 Lawrence M Friedman and J Ladinsky "Social Change and the Law of Industrial Accidents" (1967) 67 Colum L Rev 50, 54.

$8 \quad$ Farwell $v$ The Boston and Worcester Rail Road Corporation (1842) 4 Metcalf 49. 
employee took into consideration the risk of industrial accident when he or she entered into the employment contract, and the remuneration included that. (Presumably the employee could use some of the remuneration to purchase insurance, although of course few did). ${ }^{9}$

Whatever the technical underpinning, it was not a particularly realistic account of the situation in a large industrial establishment where "a servant has as little opportunity of guarding against negligence of many of his fellow servants as a member of the public; and he could hardly be said to have consented to abide risks of which he had neither knowledge nor means of knowledge". W S Holdsworth goes on that "[t]he limitation thus imposed on the liability of employers was far too strict - a truth which is emphasised by the fact that no other country in Europe has adopted any similar doctrine". ${ }^{10}$

Thus statute law began to take a role, probably beginning with the British Fatal Accidents Act 1846, which was imported into New Zealand law via the English Acts Act 1854. ${ }^{11}$ Bismark's Germany enacted statutory protection for workers in 1884, and a decade later the British Parliament passed the Workmen's Compensation Act 1897 with New Zealand following with the Worker's Compensation Act 1900. As J W McDonald shrewdly observes of the British statute: ${ }^{12}$

It was immediately occasioned by the agitation in respect of the question of contracting out, but the true foundation of the measure is found in the development of the industrial system and the inadequacy of the common law and existing statutory law to deal with the problems, social and economic, which the system brought in its train.

A third statutory strand was the Social Security Act 1938, which provided benefits for those who were sick or ill, the effect of which was to provide a minimum level of income for those who were injured. Unlike workers' compensation that income was not earnings related, and there was no compensation where a person returned to work even though their earning capacity and enjoyment of life had been diminished.

The ACC, based on a contributory scheme providing earnings related benefits, sits uneasily beside the social security system funded from general taxation with flat rate benefits. The best opportunity to integrate collapsed with the revocation of the Third Labour Government's New Zealand Superannuation Scheme, with its first tier social security based, and a second tier which was like ACC in that it was contributor and earnings related (although contribution determined).

$9 \quad$ Farewell v Boston \& Worcester Rail Road (1842) 45 Mass 49.

10 William S Holdsworth A History of English Law (Methuen, London, 1937) Vol VIII 481-2.

11 Ian B Campbell Compensation for Personal Injury in New Zealand: Its Rise and Fall (Auckland University Press, Auckland, 1996).

12 John W McDonald (revising editor Clarence N Irvine) McDonald's Law Relating to Worker's Compensation in New Zealand (Butterworths, Wellington, 1968) 3. 
Over the years the workers' compensation law was extended, but in principle it did not cover out-of-work incidents (although it was common to claim for out-of-work injuries as occurring on the work-site - most notably, given strenuous weekends, early on Monday mornings). By 1928 it became necessary to make statutory provision for another major source of injury, the motor vehicle, when New Zealand passed the Motor Vehicles Insurance (Third-Party Risk) Act 1928 which required vehicle owners to take out compulsory insurance to cover other people's injuries. ${ }^{13}$

Any longer history would observe that there was a continuing refining of the common law and statutory coverage over the subsequent period. In 1956 there had been a consolidation of the Workers Compensation Act 1956, and in 1961 there had been a Committee of Inquiry into Absolute Liability. In 1966 the Government established a Royal Commission to inquire into and report upon Workers' Compensation. (The Criminal Compensation Act 1963 was also incorporated into the final scheme.)

\section{THE PROBLEM THAT THE WOODHOUSE COMMISSION FACED}

Although the terms of reference of the Royal Commission are bland, its report opens with a feisty summary under the heading "The Problem": ${ }^{14}$

One hundred thousand workers are injured in industrial accidents every year. By good fortune most escape with minor incapacities, but many are left with grievous personal problems ... This is not all. The same work force must face the grave risks of the road and elsewhere during the rest of every 24 hours ... The toll of personal injury is one of the disastrous incidents of social progress, and the statistically inevitable victims are entitled to receive a co-ordinated response from the nation as a whole. They receive this only from the health service. For financial relief they must turn to three entirely different remedies, and frequently they are aided by none.

The negligence action is a form of lottery. In the case of industrial accidents it provides inconsistent solutions for less than one victim in every hundred. The Workers' Compensation Act provides meagre compensation for workers, but only if their injury occurred at their work. The Social Security Act will assist with the pressing needs of those who remain, provided they can meet the means test. All others are left to fend for themselves. Such a fragmented and capricious response to a social problem which cries out for co-ordinated and comprehensive treatment cannot be good enough. No economic reason justifies it. It is a situation which needs to be changed.

So the compensation problem has evolved somewhat from the medieval one of resolving vengeance and encouraging deterrence (although the Royal Commission was insistent that prevention was a part of its scheme's five principles).

13 The details of these statutory developments are in Campbell above, Chapters 1 and 2.

14 Compensation for Personal Injury in New Zealand: Report of the Royal Commission of Inquiry (Government Printer, Wellington, 1967) [Woodhouse Report]. 
However there was one other problem which is not explicitly mentioned in the opening, but which was crucial to its resolution. Not only was the existing system fragmented and capricious, it was very expensive. The Royal Commission thought the administration expenses of the scheme were 42 per cent of the amount paid out in claims. ${ }^{15}$ It thought its proposed scheme could be run for 11 per cent. ${ }^{16}$ That is an efficiency gain of over 20 per cent for the entire scheme. It used that gain to fund the comprehensive scheme - indeed had it not, the scheme could not have been as efficient.

Of course those in the administration system, including lawyers, who were beneficiaries of the scheme would lose out, but the effect of the switching of transaction costs into transfers was to coopt the public and their representative lobbyists. (Not all lawyers opposed the scheme.)

In the end this substantial efficiency gain made the revolutionary scheme possible. It also explains why it has never been possible to extend the scheme to sickness beneficiaries, despite the evident inequity between the difference of treating sickness victims by flat rate social security benefits and accident victims by earnings related accident compensation.

There is simply no twenty per cent efficiency gain to fund a comprehensive sickness system.

For completion it may be mentioned that the scheme as implemented addressed some other problems, most notably that of compensation for medical misadventure where the looming example of the United States tort practices - perhaps one could say "excesses" - were avoided by incorporating misadventure into the overall scheme.

\section{THE FUTURE OF ACCIDENT COMPENSATION}

This paper is largely a retrospective account of the early history of the accident compensation scheme until 1967. Much has happened since. Is there anything we can learn from that history which might provide pointers for the future? The simplest message is that subsequent changes have not been as problem orientated as the Royal Commission's proposal was.

Too often public policy debate, and even public policy development, is driven by solutions rather than problems, ignoring the wisdom "if it ain't broke, don't try to fix it". (The more cautious version is "if it ain't very broke, don't try to fix it".) Advocates are anxious to impose their policy answers to an issue, without any attention to what the problem might be.

There are various covert reasons for solutions-driven policy. Much of recent change seems to have been driven by ideological objectives the reformers will not articulate because they knew they would be politically unacceptable, or by a Promethean insistence that the policy should conform to a particular "ideal" model. Sometimes the idealisation is riddled with nostalgia, with little attention to the historical facts, as for calls to return to common law for accident liability. The history of the

15 Woodhouse Report, above, para 444.

16 Woodhouse Report, above, para 445. 
doctrine of common employment gives little comfort as to the efficacy of such a reversion. Indeed statutory protection was introduced because common law was not able to adapt fast enough. Moreover, as the Woodhouse proposals demonstrate, common law can have very high transaction costs. Even so, common law exists as a backup to statute law, and as illustrated by Ailsa Duffy's paper, where concerns are not adequately covered by statute law, it comes into its own - albeit clumsily. ${ }^{17}$

Another common reason for hiding the true reasons for advocating a particular solution-driven policy, is that it is intended to redistribute income to the advocate and her or his employers, and away from others. That probably has been a major factor in recent changes. The clue that this is happening is when the rent-seekers claim unproven efficiency gains which are likely to be small in actuality, and never mention the redistributive impact which is likely to be large. Very often the advocation of solutions driven policy is bolstered by a list of pseudo-problems which have only a tenuous connection with any outcome the solution could deliver.

This is not to say there is no case for carefully designed reforms based upon systematic analysis of a well defined problem. But typically any successful changes will be small and incremental rather than large and radical. Occasionally there will be reforms which are the latter. The Woodhouse proposal for compensation was one such example. Its success was based upon identifying a substantial efficiency gain and using the gain to co-opt a large proportion of the population to the reform. But it was founded on a clear understanding of the policy problem, based on analysis and a sensitivity to history. Instructively, it summarised the problem in a mere 250 words (including those outlined above). The summary gives no indication of what the solution might be, and so does not confuse them.

If there is but one operational lesson in policy development from the Woodhouse Commission, it is to construct a problem summary. Others may not be able to be as clear and succinct, so let us give them the inefficiency margin which Woodhouse eliminated in the system of personal injury, and invite policy advocates to provide an account of the problem they are addressing (independent of the solution they seek) in, say, 320 words. Such a requirement would eliminate a lot of inefficient advocacy of solution-driven policy.

17 Ailsa Duffy "The Common Law Response to the Accident Compensation Scheme" (2003) 34 VUWLR, 367. 